\title{
Economics of Common Bean (Phaseolus Vulgaris L) Seed Marketing By Smallholders Producers in Boricha District, Sidama Zone, Southern Ethiopia
}

\author{
Tamiru Teffo Galgalo $^{1} \quad$ Fitsume Wakweya Bayissa $^{2}$ Zerhun Ganewo Galato ${ }^{3}$ \\ 1. Sidama Zone Cooperative and Marketing Department, Southern Ethiopia \\ 2.Agricultural Economics Department, Hawassa University, P. box 05 \\ 3.Agribusiness and Value Chain Management Department, Hawassa University, P. box 05
}

\begin{abstract}
This study was conducted in Boricha district to examine the performance of a common bean seed market and determinants of bean seed supplied to the market. In Ethiopia, seed sector analyses have focused on generic marketing and production processes. However, sector-specific studies are important to measure the different economic aspects of production and productivity. The data was collected from 140 bean seed-producers by using an interview schedule. Descriptive statistics and multiple linear regression models (MLR) were used to analyze the data. Four bean seed marketing channels were identified. A high volume of 1179 quintals of bean seed was marketed through the producers-primary cooperatives-unions-governments-consumers channel and the lowest quantity of 378 quintals were marketed through the producers-local collectors-wholesalers-retailers-consumers channel. Among all actors in the chain, $47 \%$ of gross profit generated by producers. Government-owned organizations that are responsible for moving seed from different marketers to farmers have generated a minimum gross profit of $2.5 \%$. The MLR result indicated that educational status $(\mathrm{p}<0.01)$, farm gates price expectation $(p<0.05)$, access to market price information $(p<0.01)$ and farm experience $(p<0.01)$ significantly determined the marketed supply of bean seed. Therefore, adequate functional adult education, timely and accurate market price information and farm experience skill development are policy directions towards improving the farmers' market participation.
\end{abstract}

Keywords: Bean seed, multiple linear regressions, Channels, marketed supply, generic, sector-specific

DOI: $10.7176 / \mathrm{JMCR} / 67-03$

Publication date: April $30^{\text {th }} 2020$

\section{INTRODUCTION}

Background of the study: due to increased demand in both domestic and international markets, the production and supply of pulses have increased. These, in turn, are improving the farmers' income (Shahidur et al., 2010). In Ethiopia's lowland and midland, households mostly depend on haricot bean for cash and even termed as a protein of a poor. The cropping pattern of haricot bean showed that it can either grow in a full stand or intercropped with other cereals (Rahmeto, 2007). In a cropping system of smallholder farmers, haricot bean is grown throughout the country. Since a long before, in Ethiopia, the haricot bean is used for generating foreign currency and be consumed with many traditional dishes (Ferris and Kaganzi, 2008; MOA, 2014). According to MOA (2014), there are about 50 varieties of haricot bean is currently in the production system. The pure red and white are the most market demanded varieties (Ferris and Keganzi, 2008). In the red category; red Wolaita, medium-sized pure light red; Nasser, small pure dark red and red Melka, a mottled medium size are commercially acceptable. In the 2009/10 budget year, the total pulses export volume was 232 thousand tons. As it is classified by crop type, haricot bean covers $35 \%$, horse bean share $26 \%, 23 \%$ chickpeas and the remaining lentil, green mung beans. Out of the total earning value, the haricot bean has about 35\% share (Frehiwot, 2010).

To attain food security and economic development, the supply of improved, certified and high-quality seeds are critical to scaling up agricultural production and productivity. "Seed marketing and supply chain management approach should be vibrant, commercial, and pluralistic sectors that to be developed and coherent programs and policies created so that farmers` seed demands can be met" (Thijssen, 2011). In Ethiopia, the formal seed sector only covers the small portion of the seed demand of smallholders. Majorly, seed production through small-scale farmers is considered taking into consideration the importance of the informal seed sector. Farmers based seed production has the advantages of a variety of diffusion within communities via farmers to farmers seed exchange (Olani Nikus, 2010). The majority of actors across the seed value chains are small and informal with limited resources and gaps in funding and technical skills. This imposes barriers to agricultural growth, the efficient scale of activities, high transaction costs and inefficient information flows from the end market to producers.

Smallholder farmers are the most important sources of haricot bean produce for economic growth and poverty reduction, smallholder market supply is important to enhance the economy and ensure food security. Due to the fact that most of the benefits fetched from the marketing processes are goes to the hands of 
intermediaries and some producers do not participate in the market. By using the available opportunities, a wellorganized marketing system can maximize the income of all actors along the market chain given the growing demand in international markets for common bean (Yayneabeba and Tewodros, 2013).

Statement of the problem: Seed is an important catalyst for the development of agriculture and its foundation, quality production, and seed marketing are critical for sustained agricultural growth and food security (Atilaw and Korbu, 2011). Most of the actors along the seed market chain are the inefficient scale of activities and insufficient flow from the end market to the producers (BMF, 2010). According to Boricha district Agricultural Development office, a common bean crop is the second important crop following to the maize, but only a few farmers are responsible for providing improved common bean seed to Sidama Zone and another neighboring woreda of the region. From this point of view, common bean seed demand potential is not matching for the following five years from 2014 to 2018. Studies conducted by Hussein (2009) and Alemu (2010) showed that in Ethiopia seed market chains are concentrated on general seed market chain linkage and factors affecting the marketing conditions. A well-developed seed value marketing system creates an economic incentive for producers. Several studies have carried out so far on the seed sector focused on the generic market chain and but fail to consider specific commodities. In fact, commodity-specific studies have great contributions to develop policies and strategies that could help to solve the existing bottlenecks. This entails a need for a more comprehensive study that rigorously examines the common bean seed market chain in the study district. Therefore, this study intended to identify determinants that affect common bean seed quantity marketing by farmer-based seed producers, identifying major actors and their roles and linkage among the main actors along the market chain.

Objectives of the study: The general objective of this study was intended to analyze the economics of common bean seed marketing by smallholders in the case of Boricha district of Southern Ethiopia.

The specific objectives were

- Analyzing the marketing performance of a common bean seed and

- Determinants of the quantity of common bean seed supplied to the market by smallholder seed producers.

\section{MATERIALS AND METHODS}

Description of Study Area: Boricha district is found in Southern Nations Nationalities and Peoples' Regional State of Sidama Zone Its geographical location extends from 6046 ' $\mathrm{N}$ and 38004'ETO $7001^{\prime} \mathrm{N}$ and $38024^{\prime} \mathrm{E}$. The districts have two cropping seasons, Meher and Belg. More than $90 \%$ of the population earns their living from agriculture and livestock and the remaining earn their living from trade and other livelihood activities. The main crop coverage in the district 2016 is Maize 8,620 hectares, Haricot bean 7,400 hectares and Inset 2587 hectares is among the major ones. Sweet potato 1408 hectares and Potato 2500 hectares are grown moderately whereas Coffee, Banana, Avocado and Sugar cane grew in a very limited amount (BADO, 2014).

Research design: among non-experimental research designs, for this particular study cross-sectional survey design was applied. Qualitative and quantitative data were collected from both primary and secondary sources. The primary data was collected from sample producers, traders (wholesalers, retailers) and consumers. The secondary data was obtained from the annual agricultural reports of the district, the central statistical agency of Ethiopia and published documents. Moreover, focused group discussion, key informants interview, and personal observation were carried at the field level.

Sampling techniques and sample size determination:

Sampling techniques: A multi-stage sampling procedure was applied to draw the required number of sample units for the study. In the first stage, Boricha district was selected purposively as it is one of the major potential areas for common bean seed production in the zone. In the second stage, among 42 Kebeles ${ }^{1}$ found in Boricha district, among six kebeles that participated in producing and marketing common bean seed were selected, four kebeles were selected by using simple random sampling techniques. Finally, among a total of 832 households who were producing and marketing common bean seed in the selected four kebeles, 140 households were selected by applying systematic random sampling techniques allocating the appropriate sample for each kebele based on probability proportional to size. Green (1991) proposed a sample size determination procedure based on the rule of thumb that is $\mathrm{N} \geq 50+8 \mathrm{~m}$ developed. Where $\mathrm{N}$ is sample size and $\mathrm{m}$ is the explanatory variables proposed to be included in the econometric model. Accordingly, a sample size greater or equal to 130 is appropriate. In order to compensate non-response to the questionnaire, by adding ten samples, data would be collected from 140 common bean seed grower households. Finally, simple random sampling techniques would be employed to select respondent households. The sample size from each Kebele would be determined based on probability proportional to the size of common bean seed growers in each of the two selected rural kebeles. By following the probability proportional to the size, the sample from each kebele is described as follows in

${ }^{1}$ Kebele is the smallest administrative structure in Ethiopia 
Table 1

Table 2: Sample size from the four selected kebeles

\begin{tabular}{|l|l|l|}
\hline Kebeles & No of HHs & Seed producers \\
\hline Shelo Balela & 255 & 42 \\
\hline Konsore Haranja & 122 & 21 \\
\hline Hanja Goro & 106 & 18 \\
\hline Sadamo Chala & 349 & 59 \\
\hline Total & 832 & 140 \\
\hline
\end{tabular}

Source: Boricha district Agricultural Office

Method of Data Analysis: Both descriptive and econometric methods of data analysis were used. Percentages, means, and standard deviations and it was employed in the process of examining and describing marketing functions, household characteristics, the role of intermediaries in the market. Using spreadsheets, the data were cleaned of any outliers and entry errors.

\section{Marketing Margin Analysis}

The marketing margin measures the share of the final selling price that is captured by a particular agent in the marketing chain. It includes costs and typically, though not necessarily, some additional net income (Mendoza, 1995). Three measure marketing margins are done in the paper. All these three measurements are described as follows;

Total Gross Marketing Margin (TGMM) is always related to the final price or the price paid by the end consumer and is expressed as a percentage

$$
\mathrm{TGMM}=\frac{P c-P p}{P c} \times 100
$$

Where:

TGMM is total gross marketing margin

$\mathrm{Pc}$ is the consumer price

$\mathrm{Pp}$ is the producer price

Gross (profit) margin (GMPP) is the difference between sales revenue and cost price, expressed as a percentage of the cost price or as a discounted percentage of the sales price.

$$
\text { GMMP }=\frac{\text { End buyer price-Marketing Gross margin }}{\text { End buyer price }} \times \mathbf{1 0 0}
$$

Net marketing margin (NMM): is the percentage over the final price earned by the intermediary as his net income once his marketing costs are deducted.

$$
\mathrm{NMM}=\frac{\text { Gross margin }- \text { Marketing cost }}{\text { End buyer price }} \times 100
$$

\section{Econometric Model Specification}

To address the research objective of determinants for the quantity of haricot bean seed supplied to the market, multiple linear regression models were applied. Its goal is to model the relationship between the explanatory and response variables. It is based on the least-squares: the model is fit such that the sum-of-squares of differences of observed and predicted values is minimized.

Model specification: The model expresses the value of a dependent variable as a linear function of one or more independent variables and an error term:

$$
\mathrm{Yi}=\mathrm{X}^{\prime} \beta+\mathrm{U}
$$

Where:

$\mathrm{Yi}=$ common bean seed marketed volume/quintal

$\beta=$ a vector of estimated coefficient of the explanatory variables

$\mathrm{X}=\mathrm{a}$ vector of explanatory variables

$\mathrm{U}=$ disturbance term

\section{RESULTS AND DISCUSSION}

Demographic characteristics of respondents

Survey results showed that out of the 140 sample respondents participated in common bean production the majority (81\%) were male whereas the remaining (19\%) were women. The age of the sample household ranged from 26 to 42 years and the average age of the total sampled households was 30 years. With regard to the marital 
status of the respondents, about $71 \%$ of the sample respondents were married, $9 \%$ single, $4 \%$ widowed and $16 \%$ divorced. Better educated farmers tend to be more innovative and are therefore more likely to adopt the marketing systems.

The age of the sample household ranged from 22 to 42 years and the average age of the total sampled households was 35 years. In this study, the general farming experience of common bean seed production is considered to positively contribute to common bean seed production and marketing from accumulated knowledge and skill from 140 respondents 2, 22 and 8.4 minimum, maximum and mean experienced respectively. Better educated farmers tend to be more innovative and are therefore more likely to adopt the marketing systems. The survey result shows that the educational level of sample respondents among the 140 respondents; $9 \%$ of respondents were illiterate, $41 \%$ were $0-4$ grade complete, $39 \%$ were $5-8$ grade complete and $11 \%$ were $9-10$ grade complete.

\section{Land use pattern}

As depicted in Table 2, the average land allocated for common bean seed production of 0.91 hectares. This shows that the area was known for its high production of common bean.

\section{Sources of income for households}

In the study area, sample households were found to generate income from on-farm and off-farm activities. Means of generating cash income from on-farm activities were crop productions such as; maize, haricot bean, potato, and sweet potato and livestock activities such as poultry production, poultry egg production, and milk and milk products. Off-farm activity is considered a crucial factor since it is important for the household economy and it is also a critical survival strategy for rural farm households.

\section{Common Bean Production and Marketing in Boricha district}

Common bean is one of the economically important crops in the area next to maize. However, the area was one of the food-insecure areas. The Agro-ecology of the District is lowland and midland. However, almost all of the farmers who live in lowland kebele engaged in common bean and maize production. Common bean marketing occurred throughout the year. Since most of the farmers store commonly from 3-5 months until they need cash, saving purpose and better price expectation. Rural collectors, wholesalers, cooperatives, union and retailers are major actors of movements of common bean trade-in in the study area.

\section{Common Bean Seed Market Channels and Performance Analysis}

The major actors in the channels were producers, rural collectors, rural wholesalers, primary cooperatives, unions (processors), retailers and consumers. There were three alternative buyers that purchased common bean directly from sample households. Among the total production marketed common bean 2846 quintals or (84\%) from this $70.9 \%$ was purchased primer cooperatives, $13.6 \%$ by locale collector, $15.5 \%$ by grain producerconsumer.

The total of 2846 quintals (84\%) common bean seed was marketed from producers to consumers through four market channels in its way to reaching the ultimate consumers. The volume of common bean seed flown into the market and end buyers within the channels significantly differs for each channel. From identified four common bean seed marketing channels, the largest and smallest volume flowed through channels III and IV which was 1179 and 378 quintals respectively. The volume that transacted through channel three was most important since it accounted for the largest marketed volume of 1179 quintal. The major identified marketing channels of common bean seed were explained in figure 2 .

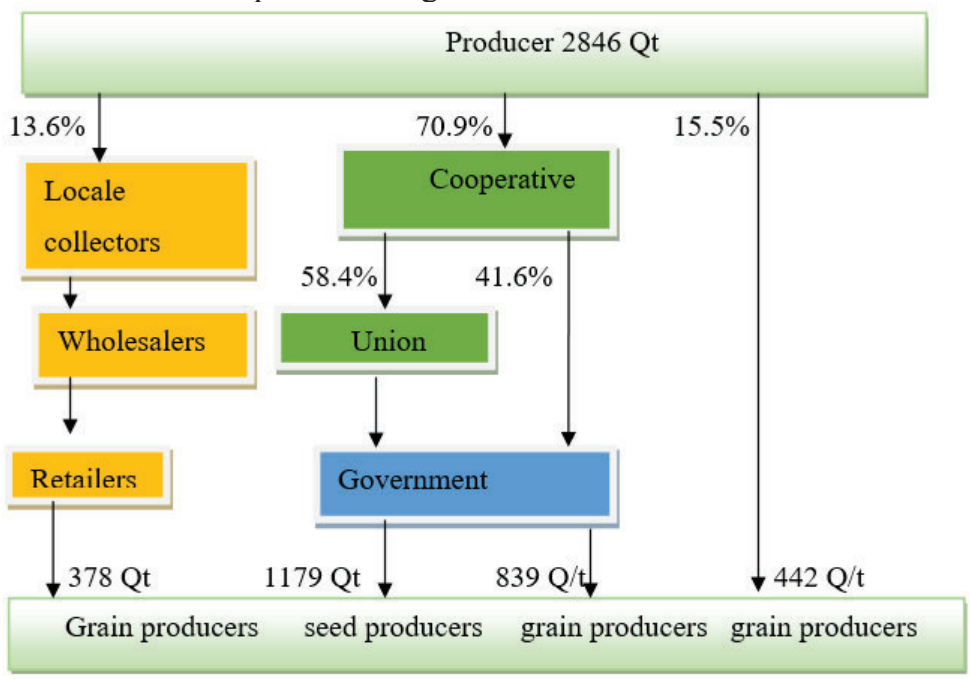

Source: Field survey, 2019

Fig 2: Common bean seed marketing channels 


\section{Common bean production Cost}

Production costs such as basic seed seeds, fertilizers, and labor were computed as production costs. The average cost of a common bean seed production cost for a sample household was $1879 \mathrm{ETB} /$ per hectare, the average cost of labor was 358 ETB per hectare and the average cost of fertilizer incurred 975 ETB for per hectare. From the total cost, $58 \%$ cost share was basic seed cost, $30.4 \%$ cost share was fertilizer cost and $10.6 \%$ cost share was labor cost share.

Table 3: Land allocated for different crops

\begin{tabular}{|l|l|l|l|l|c|}
\hline \multicolumn{1}{|c|}{ Variables } & $\mathrm{N}$ & Minimum & Maximum & Mean & Std. deviation \\
\hline Own land in hectare & 140 & 1 & 3 & 1.8 & 0.64 \\
\hline Land to common bean & 140 & 0.5 & 1.5 & 0.91 & 0.22 \\
\hline Allocated land to maize & 140 & 0 & 1 & 0.66 & 0.43 \\
\hline Allocated land to another crop & 140 & 0 & 1 & 0.34 & 0.43 \\
\hline
\end{tabular}

Source: Own survey, 2019

Table 4: Common bean seed production cost/hectare

\begin{tabular}{|l|l|l|l|l|l|}
\hline Variables & N & Minimum & Maximum & Mean & $\%$ \\
\hline Seed purchasing cost & 140 & 600 & 3400 & 1879 & 58.7 \\
\hline Labor cost & 135 & 100 & 600 & 358 & 10.8 \\
\hline Fertilizer cost & 140 & 500 & 1300 & 975 & 30.4 \\
\hline Total cost & 140 & & & 3212 & 100 \\
\hline
\end{tabular}

Source: computed from the survey, 2019

Table 5: Producer marketing cost per quintal

\begin{tabular}{|l|l|l|l|l|l|}
\hline \multicolumn{1}{|c|}{ Variables } & $\mathrm{N}$ & Minimum & Maximum & Mean & $\%$ \\
\hline Loading and unloading cost & 140 & 3 & 5 & 4.32 & 7.3 \\
\hline Transportation cost & 140 & 14 & 36 & 21 & 36 \\
\hline Cost of brokerage & 8 & 10 & 20 & 15 & 1.4 \\
\hline Sales tax cost & 73 & 2 & 2 & 2 & 1.7 \\
\hline Sorting cost & 140 & 14 & 50 & 30 & 51 \\
\hline Other cost & 9 & 20 & 22 & 21 & 2.3 \\
\hline Total marketing cost & & & 93.6 & 100 \\
\hline
\end{tabular}

\section{Source: Field Survey, 2019}

\section{Common Bean Seed Producer Marketing Cost (per quintal)}

The marketing costs that producers incurred in the value chain were $51 \%$ for sorting $36 \%$ transportation, $7 \%$ loading and unloading, $1.7 \%$ for sales tax, and $1.4 \%$ for brokerage fee and $2.3 \%$ for another cost. According to the survey result (Table 4), sorting cost had higher share next to transporting cost

\section{Common Bean Seed Marketing Cost in Different Actors /per quintal}

The major actors in the common bean seed value chain were producers, rural collectors, rural wholesalers, cooperatives, unions, local government and retailers. When the commodity flows from producers to consumers, actors in the value chain add costs. Common bean seed produced by farmers passed through one actor to another, the actors improved the product quality by sorting, and creating time utility as well incur some cost. As indicated in Table 5, higher marketing cost was incurred by unions followed by a primary cooperative per quintal. 
Table 6: Marketing costs long different actors

\begin{tabular}{|c|c|c|c|c|c|c|c|}
\hline Cost item & Producers & Collector & Wholesalers & Retailers & Coops & Unions & Gov.ts \\
\hline Purchasing price & & 1050 & 1200 & 1300 & 1300 & 1500 & 1500 \\
\hline Production cost & 128 & & & & & & \\
\hline Marketing cost: & 93 & & & & & & \\
\hline Cost of sorting & & 25 & 29 & 20 & 38 & 45 & \\
\hline Cost of packing & & 12 & 13 & 0 & 13 & 17 & \\
\hline Loading\& unloading & & 4 & 4 & 3 & 4 & 5 & 4 \\
\hline Cost of storage & & & 20 & & & & 20 \\
\hline Transportation cost & & 20 & 15 & 10 & 60 & 65 & 30 \\
\hline Cost of grading & & & & & 110 & 130 & \\
\hline Total cost & 221 & 51 & 61 & 33 & 225 & 262 & 54 \\
\hline Selling price & 1100 & 1250 & 1350 & 1400 & 1500 & 2100 & 1600 \\
\hline Market margin & 879 & 250 & 150 & 100 & 300 & 600 & 100 \\
\hline$\%$ share of margin & 42 & 12 & 14 & 5 & 14 & 28 & 4 \\
\hline Gross profit & 786 & 139 & 149 & 192 & 66 & 273 & 41 \\
\hline$\%$ share of profit & 47 & 8.4 & 9 & 12 & 4 & 17 & 2.5 \\
\hline
\end{tabular}

Source: Computed from field survey, 2019

Marketing margins of common bean seed in different channels

Gross Marketing Margins and Net Marketing Margins were computed for the major actors. As depicted in Table 6 , there was a difference in the consumers' price spread along the market channels where channels III and II had the highest and lowest total gross marketing margin of $42.5 \%$ and $18.75 \%$ percent respectively. The market channels with only one actor between producers and consumers showed low TGMM. In channel IV, 30\% of common bean seed price was added when it reached to final consumers. This implied that as the market margin becomes wide, price becomes high for consumers and low to producers. From all actors, producers have got the highest GMM in channel I when they sell directly to a consumer but this channel conveys a limited amount of common bean marketed.

Table 7: Market share in different actors

\begin{tabular}{|c|c|c|c|c|}
\hline & & & Market channel & \\
\hline Marketing margin & I & II & III & IV \\
\hline TGMM $\%$ & & 18.5 & 42.5 & 30 \\
\hline GMM producer & 100 & 81 & 58 & 70 \\
\hline GMM collector & & & & 13 \\
\hline GMM wholesaler & & & & 13 \\
\hline GMM retailer & & & & 3.4 \\
\hline GMM cooperatives & & 12.5 & 9.5 & \\
\hline GMM union & & & 28.5 & \\
\hline GMM government & & 6 & 4.5 & \\
\hline TNMM $\%$ & & 11.89 & 32.5 & 38 \\
\hline NMM producer & & 88 & 67.4 & 62 \\
\hline NMM collector & & & & 11 \\
\hline NMM wholesaler & & & & 12 \\
\hline NMM retailer & & & & 15 \\
\hline NMM cooperatives & & & 5.6 & \\
\hline NMM union & & 7.3 & 23.4 & \\
\hline NMM government & & 4.5 & 3.5 & \\
\hline
\end{tabular}

Source: computed from field survey, 2019

\section{Factors Affect the Market supply of Common Bean Seed}

Multiple linear regression models were employed to determinants for the Common Bean Seed supply. Before fitting the data in the model, different tests were carried. The most essential problems of OLS are multicollinearity and heteroscedasticity but this was detected and it was performed using appropriate test statistics for variables. The VIF values for the explanatory variable were ranging between 1.5 and 6.39 and the mean VIF value was 3.23 . The results showed that there is the absence of serious multicollinearity problems among independent variables.

Among 10 explanatory variables hypothesized to determine the household level market supply of common bean seed four variables namely; educational status, farm gates price expectation, market price information access and farm experience were found to be significant. Regarding the relationship of the variables with the 
volume of common bean seed marketed; educational level, farm gates price expectation, market price information access and farm experience had a positive relationship. The adjusted $\mathrm{R}^{2}$ value was 0.799 and this implying that $79.9 \%$ of the variation in the dependent variable was explained by the explanatory variables under consideration.

Table 8: Determinants for the quantity of haricot bean seed supplied to the market

\begin{tabular}{|l|l|l|l|l|}
\hline Variables & Coefficients & Std. Error & t-value & P-value \\
\hline (Constant) & 3.727 & 3.702 & 1.007 & .316 \\
\hline Educational status & $2.478^{* * *}$ & 0.565 & 4.384 & .000 \\
\hline Time taken to the market & -0.022 & 0.020 & -1.071 & .286 \\
\hline Credit access & 0.738 & 1.025 & .720 & .473 \\
\hline Farm gate price expectation & $7.264^{* * *}$ & 1.877 & 3.871 & .000 \\
\hline Total Transaction cost & 0.014 & 0.029 & .507 & .613 \\
\hline Extension agent contact times & 0.467 & 0.281 & 1.661 & .099 \\
\hline Market price information access & $2.476^{* *}$ & 1.046 & 2.367 & .019 \\
\hline Farm experience & $0.389^{* * *}$ & 0.101 & 3.862 & .000 \\
\hline Farm land allocation & 1.936 & 3.510 & .552 & .582 \\
\hline Source con
\end{tabular}

Source: computation from own survey, 2019

Educational status: As prior expectation, education is significant at $1 \%$ significance level $(\mathrm{p}=0.000)$. This implies that as the years of formal education attended increases by one year, the common bean seed supplied will increase by 2.478 quintal. Further, educated farmers can have more access to knowhow and understand the benefit of the utilization of appropriate technology and agricultural input. This is also in line with the findings by Astewel (2010) who illustrated that if puddy producer gets educated, the amount of puddy supplied to the market increases, and this suggests that a higher level of education provides a greater opportunity for the farmers to participate nine the pineapple market. Similar if extension contact increase by one unit, the quantity supplied will increase by 0.467 quintals.

Experience in common bean farming: Is one factor that affects market supplied quantity of common bean seed has positively and significantly affected by farmers' experience on common bean seed production at a $1 \%$ significance level $(p=0.000)$. On average a one year increment in the experience of common bean seed farming will increase quantity supplied by 0.389 quintals. A household with a better experience in coffee farming and processing is expected to produce more amounts of coffee than the one with only less experience and, as a result, he is expected to supply more amounts of coffee to market. Abay (2007) found that as farmer's experience increases the tomato supplied to market will increase in Fogera, South Gonder.

Information access: is also another factor, which positively affects quantity supply at a 5\% significance level $(\mathrm{p}>019)$. On average, access to market information increases the quantity supplied by 2.476 quintals. It was expected that it affects the market quantity of the common bean seed by households positively. The better information farmers have the more likely they supply to the market. This requires due attention to new market opportunities, changing needs of the consumer and how market trends influence buying (CIAT, 2004)

Perception of farmers toward farm-gate price: Is farm gate price of common bean and this is dummy variable if a farmer thinks the price is fair it has the value of one otherwise zero and as it is if the farm household head perceives that the price is fair, the quantity supplied increased by 7.264 quintals. The variable is positively and significantly affected by quantity supply at a $1 \%$ significance level $(p>000)$. This could be due to higher prices received by the common bean seed producers that generated more profits for the business. The results are consistent with Birachi et al. (2011) found that in Burundi, common bean price determined the quantity supplied to the market.

\section{CONCLUSION AND POLICY IMPLICATIONS}

The seed is an important catalyst for the development of agriculture and its foundation, quality production, and seed marketing are critical for sustained agricultural growth and food security. Common bean is an important food crop in Ethiopia, as well as the study area Boricha District. The supply of improved seed remains a critical shortage for producers in the existing demand. Hence, improving the challenges existed at the farm and marketlevel will enhance the production capacity of smallholder farmers. The government should provide seed business-oriented extension system that designed to improve farmers' understanding as experience sharing program and providing seed business training opportunities could be a potential solution to promote the local seed business in a sustainable way. Strong extension intervention is vital to assist farmers in producing highquality common bean seed and increase production through consistent follow-up and keeping of farm records. Moreover, to initiate the producers, market information services have to be strengthened to provide farmers and traders accurate and timely information on current supply, demand, and prices in the districts and national levels. 


\section{CONFLICT OF INTERESTS}

There is no conflict of interest.

\section{ACKNOWLEDGMENTS}

Profound appreciation to common bean seed producers, traders and enumerators in Boricha District for their consideration, hospitality, and willingness to participate in the survey.

\section{REFERENCES}

Alemu D.S. Rashid. (2010). Seed system potential in Ethiopia: Constraints and opportunities for enhancing the seed sector. International Food Policy Research Institute: Washington DC. Pp62.

Atilaw Abebe and Lijalem Korbu, (2011). Recent Development in Seed Systems of Ethiopia in Improving Farmers' Access to Seed, (Dawit Alemu, Shiratori Kiyoshi and Abebe Kirub (eds)), Empowering Farmers' Innovation, Series No. 1, FRG II Project

Astewel Takele. 2010. Analysis of Rice Profitability and Marketing Chain: The Case of Fogera Woreda, South Gondar Zone, Amhara National Regional State, Ethiopia.

CIAT (Centro International de Agricultural Tropical). (2004). Increasing the competitiveness market chains of smallholder's producers. Manual, 3: Territorial Approach to Rural Agro Enterprise Development Project.

Frehiwot Mulugeta. 2010. Profile of Haricot bean production, supply, demand and marketing issues in Ethiopia, Ethiopia commodity exchange authority, Addis Ababa.50 p.

Ferris S, Kaganzi E. 2008. Evaluating marketing opportunities for haricot beans in Ethiopia IPMS (Improving Productivity and Market Success), of Ethiopian Farmers Project Working Paper 7. ILRI (International Livestock Research Institute), Nairobi, Kenya.68p.

Greene, W. H., 2003. Econometric Analysis, Fifth edition. Pearson Education International,USA.

Negash R., (2007). "Determinant of adoption of improved haricot bean production package in Alaba special woreda, Southern Ethiopia," Unpublished M.Sc. Thesis, Haramaya University, Ethiopia

Mendoza. G. (1995). A Primer on Marketing Channels and Margins. Lyme Rimer Publishers Inc.

Ministry of Agriculture. 2014. Plant variety release, protection and seed quality control directorate. Crop variety registers. Issue No.17. Addis Ababa, Ethiopia. P290.

Olani Nikus. (2010). Wheat pre- basic seed multiplied on farmer's field. by Printed in Ethiopia May 2010. woreda, south Gondar zone, Amhara national regional state, Ethiopia,. M.Sc theis, Haramaya University.

Thijssen, M.H., Z. Bishaw, A. Beshir and W.S. de Boef. 2008. Farmers, seeds and varieties: supporting informal seed supply in Ethiopia. Wagenengen International 348 p.

Shahidur R.,ChilotY.,BefekaduB., and Solomon L.,2010. Pulses value chain in Ethiopia; constraints and opportunities for enhancing exports. International Food Policy ResearchInstitute.

Yaynabeba Abayneh and Tewodros Tefera 2013. Factors influencing market participation decision and extent of participation of haricot bean farmers in Meskan District, Ethiopia. International Journal of Management and Development Studies. Volume No. 2 (2013).

Wenyan Han, Xin Li, Peng Yan, Liping Zhang and Golam Jalal Ahammed. 2018. Tea Research Institute of the Chinese Academy of Agricultural Sciences (TRI, CAAS), China. 